\title{
Zeytin Yaprağı Ekstresi ve Propolisin Herpes Simpleks Virüsü Tip 1 Üzerine Antiviral Etkisinin Asiklovir ile Karşılaştırılması
}

\author{
Comparison of Antiviral Effect of Olive Leaf Extract and \\ Propolis with Acyclovir on Herpes Simplex Virus Type 1
}

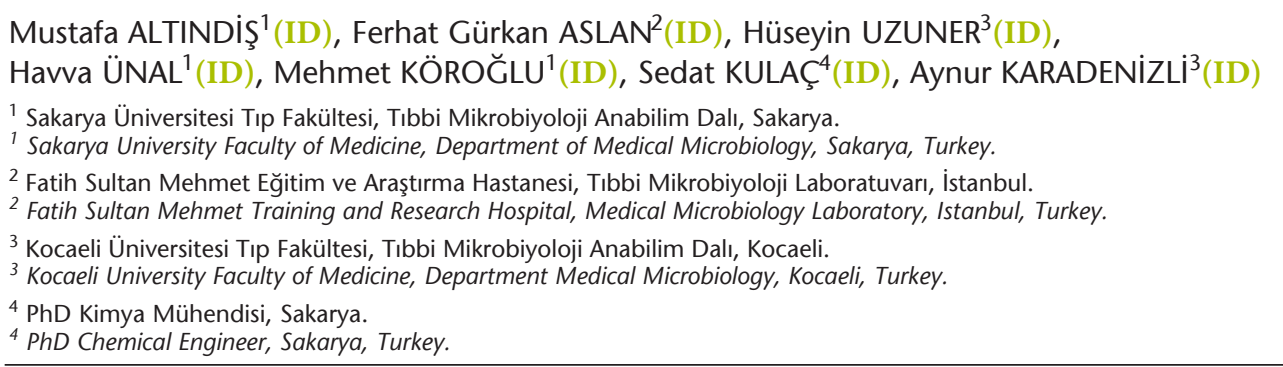

* Bu çalışma Sakarya Üniversitesi Bilimsel Araştırma Projeleri Koordinatörlüğü tarafından desteklenmiştir.

Makale Atıfı: Altındiş M, Aslan FG, Uzuner H, Ünal H, Köroğlu M, Kulaç S ve ark. Zeytin yaprağı ekstresi ve propolisin herpes simpleks virüsü tip 1 üzerine antiviral etkisinin asiklovir ile karşılaştırılması. Mikrobiyol Bul 2020;54(1):79-94.

\section{ÖZ}

Herpes simpleks virüsü tip 1 (HSV-1) tedavisinde; bir nükleoz(t)it analoğu olan asiklovir kullanılmakla birlikte, bu tür ilaçların sık kullanımı sonucunda, son dönemde ilaca dirençli virüslerin ortaya çıkması ve bu ilaçların toksik yan etkileri, tedavide yeni aktif moleküllerin araştırılmasına olan ihtiyacı artırmışır. Tıp bilimleri ve farmakolojideki sentetik molekül geliştirme çalışmalarına rağmen, biyolojik olarak aktif bileşiklerin doğal bir kaynağı olan bitkiler, tüm dünyada popüler olmaya devam etmektedir. Bu in vitro çalışmada, zeytin yaprağı ekstresi ve propolisin tek başına ya da asiklovir ile kombine olarak HSV-1'e karşı antiviral etkinliklerinin araştırılması amaçlanmıştır. Zeytin yaprağı ekstresi ve propolis ile propolisin çözücüsü olarak dimetilsülfoksitin, Hep-2 (ATCC, CCL-23) hücrelerine toksik dozları konvansiyonel hücre kültürü yöntemi ile belirlenmiştir. "Son nokta" yöntemi kullanılarak doku kültürünün yarısını enfekte eden viral doz $\left(\mathrm{TCID}_{50}\right)$ değeri hesaplanmış, virüs miktarları Spearman-Karber yöntemine göre belirlenmiştir. Zeytin yaprağı ekstresi ve propolisin, HSV-1 üzerine antiviral etkileri, konvansiyonel hücre kültürü ve gerçek zamanlı hücre analizi (RTCA) yöntemleriyle araştırılmıştır. Her iki ekstraktın asiklovir ve birbirleriyle kombinasyonları ise RTCA ile değerlendirilmiştir. Bu amaçla, log $\mathrm{TCID}_{50}: 11.5$ olan HSV-1 bulunan tüplere, en yüksek nontoksik konsantrasyonlarından başlanarak azalan oranlarda üç farklı dilüsyonda hazırlanan etken maddeler ilave edilmiş ve antiviral etkinliklerinin ortaya çıkması için, iki farklı zaman aralığında (bir saat ve üç saat) oda sıcaklı̆ı̆ıda bekletilmişlerdir. Bu süreler sonrasında tüplerden alınan sıvılar Hep-2 
hücreleri içeren plaklara ekilerek 72 saat sonrasında değerlendirilmiştir. Ekstraktların ve asiklovirin, HSV-1 üzerine antiviral etkinliklerinin olduğu en düşük konsantrasyondan en az dört kat daha düşük konsantrasyonları kullanılarak hazırlanan ikili kombinasyonları, xCELLigence RTCA cihazına ait e-plaklardaki Hep-2 hücrelerine ekilerek 30 dakika aralıklarla ölçümler yapılmış, veriler gerçek zamanlı olarak kaydedilmiştir. Zeytin yaprağı ekstresi ve propolisin farklı konsantrasyonlarında ve iki farklı zaman periyodu için yapılan değerlendirmede; RTCA yöntemi ile propolisin $10 \mu \mathrm{g} / \mathrm{ml}$ konsantrasyonunda, zeytin yaprağı ekstresinin ise $1.2 \mathrm{mg} / \mathrm{ml}$ konsantrasyonunda, hem bir saat hem de üç saatlik inkübasyonda antiviral etkinlik gösterdiği tespit edilmiştir. Virüs miktarındaki en fazla azalmanın olduğu konsantrasyon ve sürenin ise propolis için $10 \mu \mathrm{g} / \mathrm{ml}$ dozunda ilk bir saat içerisinde; zeytin yaprağı ekstresi için $1.2 \mathrm{mg} / \mathrm{ml}$ konsantrasyonda ve ilk bir saat içerisinde olduğu tespit edilmiştir. Propolis ve zeytin yaprağı ekstresinin her ikisinin de asiklovir ile olan kombinasyonlarında sitopatik etki gelişmediği, ekstraktların birlikteliğinde ise sitopatik etkinin geciktiği belirlenmiştir. Elde edilen sonuçlar göz önüne alındığında, propolis ve zeytin yaprağı ekstrelerinin hem tek başlarına hem de asiklovir ile hazırlanan kombinasyonlarında HSV-1 için antiviral etkinliklerinin olduğu görülmektedir. Asiklovirden farklı bir mekanizma ile olasılıkla doğrudan virüsidal aktivite, virüsün hücre içine girişinin önlenmesi veya replikasyonun erken aşamalarında viral inhibitör (viral partiküllerin hücreye bağlanması ve adsorbsiyonunun önlenmesi) şeklinde etkili olmalarının, birlikte kullanılmaları halinde asiklovir dozunda ve yan etkilerinde azalma sağlayabileceği düşünülmektedir. Aktif forma dönüştürülmeleri gerekmeyen bu ekstraktlar, oral lezyonlarda enfektivitenin azaltılmasında, yayıllımın önlenmesinde ve özellikle immün yetmezliği olan hastalarda asiklovire dirençli HSV enfeksiyonlarının topikal tedavisinde kullanılabilme potansiyeline sahiptir. Bununla birlikte, tıbbi özelliklerini ve olası toksisitelerini belirlemek için in vivo çalışmalara gereksinim bulunmaktadır. Bu bulgular, ileride yapılacak geniş ve kapsamlı çalışmalarla desteklenmeli ve diğer virüslere karşı etkinlikleri de araştırılmalıdır.

Anahtar kelimeler: Antiviral etkinlik; herpes simpleks virüsü; hücre kültürü; zeytin yaprağı ekstresi; propolis.

\section{ABSTRACT}

While acyclovir, a nucleoside analogue, is widely used for herpes simplex virus type 1 (HSV-1), emergence of drug-resistant viruses due to frequent usage of this class of medicines, and their toxic side effects require exploring novel active molecules. Despite the studies on developing synthetic molecules in medical sciences and pharmacology, herbs as a natural source of biologically-active compounds remain popular. In this in vitro study, olive leaf extract (OLE) and propolis alone or in combination with acyclovir were investigated for their antiviral efficacy in HSV-1.Toxic doses of OLE, propolis, and dimethyl sulfoxide, propolis diluent, for Hep-2 (ATCC, CCL-23) cells were determined by conventional cell culture. Using "endpoint" method, the viral dose infecting half of the cell culture $\left(\mathrm{TCI}_{50}\right)$ was calculated, and viral quantity was determined with Spearman-Karber method. Antiviral effects of OLE and propolis on HSV-1 were investigated by conventional cell culture and real-time cell analysis (RTCA). Combinations of the two extracts with one another and with acyclovir were evaluated by RTCA. Active substances prepared at three different dilutions were added to tubes with $\mathrm{HSV}-1$ of $\log \mathrm{TCID}_{50}: 11.5$ in descending order starting from the highest non-toxic concentration, and they were left at room temperature for two different durations (one hour and three hours). The aliquots taken from the tubes were cultured in plates containing Hep-2 cells and evaluated after 72 hours. Combinations of extracts and acyclovir at concentrations at least four times lower than the lowest concentration showing antiviral efficacy against HSV-1 were cultured with Hep-2 cells in the e-plates of the xCELLigence RTCA device, measurements were obtained at 30 minute intervals, and data were recorded in real time. In the test with two different durations and at different concentrations of OLE and propolis, antiviral efficacy was observed both with one-hour and three-hour incubation at a concentration of $10 \mu \mathrm{g} /$ $\mathrm{ml}$ for propolis and $1.2 \mathrm{mg} / \mathrm{ml}$ for OLE with RTCA. The duration and concentration of the greatest decrease in viral quantity were in the first one hour and $10 \mu \mathrm{g} / \mathrm{ml}$ for propolis, and in the first one hour and $1.2 \mathrm{mg} /$ $\mathrm{ml}$ for OLE. Combination of propolis and OLE with acyclovir caused no cytopathic effects, and the combination of extracts led to delayed cytopathic effect. According to these results, propolis and OLE, alone and in combinations with acyclovir, have antiviral efficacy against HSV-1. These agents may reduce the dose and side effects of acyclovir in case of co-administration since they exert their effects through a different mechanism than acyclovir, possibly through direct virucidal activity, inhibition of virus internalization or viral inhibition in early stages of replication (inhibition of adsorption/binding of viral particles to the cell). These 
extracts that do not require conversion to active form have the potential to reduce infectivity in oral lesions, prevent spread, and be used in the topical treatment of acyclovir-resistant HSV infections, particularly in immunocompromised patients. However, in vivo studies should be conducted to determine their medicinal properties and potential toxicities. These results should be supported by further comprehensive studies and the efficacy against other viruses should also be investigated.

Keywords: Antiviral activity; cell culture; herpes simplex virus; olive leaf extract; propolis.

\section{Giriş}

Herpes simpleks virüsü tip 1 (HSV-1), Herpesviridae ailesinden bir DNA virüsüdür. İnsanlardaki en yaygın enfeksiyonlardan biri olup, genel popülasyonun $>\% 70^{\prime}$ ini enfekte ettiği bildirilmiştir ${ }^{1-3}$. HSV-1 insanlarda, akut enfeksiyondan kronik hastalıklara ve asemptomatik enfeksiyondan hayatı tehdit eden ciddi hastalıklara kadar değişebilen klinik tablolara neden olabilmektedir ${ }^{4,5}$. Enfeksiyon, özellikle immün sistemi baskılanmış hastalarda, ciddi ve progresif seyretmekte olup morbidite ve mortaliteye yol açmaktadır ${ }^{2}$.

Son yıllarda tedavideki önemli gelişmeler, özellikle immün yetmezlikli hastalarda yaşam süresinin uzamasını sağlamasına rağmen, viral enfeksiyonların insidansında artış görülmektedir. Bir nükleoz(t)it analoğu olan asiklovir, günümüzde HSV enfeksiyonlarının tedavisinde kullanılan en etkili antiviral ilaçtır. Bununla birlikte, asiklovir ve ilgili ilaçların sık kullanımı sonucunda ilaca dirençli virüslerin ortaya çıkması ve bu ilaçların toksik yan etkileri (akut böbrek yetmezliği, nörotoksisite) gibi nedenlerle HSV enfeksiyonlarının tedavisinde yeni aktif moleküllerin araştııımasına olan intiyaç hızla artmaktadır ${ }^{1,6}$. Biyolojik olarak aktif bileşiklerin önemli bir kaynağı olan bitkiler yaklaşı 3000 yıldan beri tıpta kullanılmakta, tıp bilimleri ve farmakolojideki ilerlemelere rağmen tüm dünyada popüler olmaya devam etmektedir ${ }^{1,7}$.

Antiviral etkinlik çalışmalarında mikroelektronik biyosensör teknolojisine dayalı gerçek zamanlı hücre analiz sistemi (real-time cell analysis; RTCA) kullanılmaktadır. Elektronik hücre sensörü dizisi sayesinde, RTCA sistemi, işaret molekülleri olmaksızın kuyucuklarda bulunan hücrelerin hemen hemen hepsinin dinamik olarak izlenmesini sağlayabilmekte$\mathrm{dir}^{8,9}$. Hücre aracılı sitotoksisiteye, virüs aracılı sitotoksisiteye ve tedaviye tümör hücresinin yanıtına olan ilginin artmasıyla, bu sistem hücre bazlı deneyler için önem kazanmıştır ${ }^{10}$. Bu teknoloji sayesinde, hücre canlılı̆ı̆, hücre sayısı değişikliği, hücre morfolojisi, kök hücre proliferasyonu, hücre adezyonu ve yayılma, reseptör aracılı sinyalin fonksiyonel izlenmesi, hücre invazyonu ve migrasyonu, RNA interferansı, virüs aracılı sitopatojenite vb. hücresel olayların dinamik, gerçek zamanlı olarak izlenmesi gibi çok çeşitli hücre bazlı analizler noninvaziv olarak gerçekleştirilebilmektedir ${ }^{8-10}$. Bu çalışmada, Geyve'de yerel halkın kendi ağız yaralarında kullandığı, bölgelerinde yetişen zeytin yaprağının ekstresi ve propolisin tek başlarına ya da asiklovir ile kombine olarak, HSV-1 üzerindeki antiviral etkinliklerinin, konvansiyonel hücre kültürü yöntemi ve RTCA ile araştırılması amaçlanmıştır.

\section{GEREÇ ve YÖNTEM}

Bu çalışma, Sakarya Üniversitesi Girişimsel Olmayan Etik Kurul onayı ile gerçekleştirildi (Tarih: 31.03.2016 ve Karar no: E-4569). 


\section{Zeytin Yaprağı ve Propolis Ekstraktlarının Elde Edilmesi}

Zeytin yaprağı ekstraktı için Geyve zeytin yaprağı ve propolis eldesi için arı kovanlarından elde edilen örnekler kullanıldı. Propolis ve kurutulmuş zeytin yaprakları bir öğütücüden geçirilerek toz haline getirildi. Zeytin yaprağı (200 g zeytin yaprağı ve $800 \mathrm{ml}$ etanol) ve propolis (500 g propolis ve $1000 \mathrm{ml}$ etanol) \%70'lik etanolde bir saat süre ile çalkalandı. Karışımlar filtre kağıtları kullanılarak filtre edildi. Elde edilen propolis filtratı cam tüplere alınarak vakum santrifüjleri yardımıyla sıvı kısımdan ayrıldı. Çalışılıncaya kadar $-240^{\circ} \mathrm{C}^{\prime}$ de bekletilen kuru propolis ekstraktı kullanım öncesi dimetilsülfoksit (DMSO) ile çözüldü. Etanol ile çözülmüş olan zeytin yaprağı ekstraktı ise beklemeye gerek olmadan çalışmada kullanıldı $\iota^{6,11}$.

\section{Hep-2 Hücrelerinin Üretimi ve Virüs Miktarının Belirlenmesi}

Hep-2 hücreleri, \%10 fetal sığır serumu (Biochrome AG, Almanya) içeren "Dulbecco's modified eagle medium (DMEM)" (Biochrome AG, Almanya) besiyerinde üretilirken; Kocaeli Üniversitesi Tıp Fakültesi Tıbbi Mikrobiyoloji Anabilim Dalı Viroloji Laboratuvarı tarafından sağlanan HSV-1 standart suşu ise \%2 fetal sığır serumu içeren DMEM besiyerinde, \%5 $\mathrm{CO}_{2}$ içeren $+37^{\circ} \mathrm{C}^{\prime}$ lik ortamda çoğaltıldı. Virüs miktarının belirlenmesi için Hep-2 hücreleri 96 kuyulu hücre kültür plaklarında üretildi. "Son nokta" yöntemi kullanılarak doku kültürünün yarısını enfekte eden doz ( $50 \%$ tissue culture infective dose; TCID $_{50}$ ) değeri Spearman-Karber yöntemine göre hesaplandı ${ }^{12}$.

\section{Sitotoksisite Çalışmaları}

Elde edilen zeytin yaprağı ekstresi ve propolis ile propolisin çözülmesi için kullanılacak DMSO'nun, Hep-2 hücrelerine nontoksik konsantrasyonlarının belirlenmesi amacıyla toksisite deneyleri gerçekleştirildi. DMSO'nun nontoksik konsantrasyonunu belirlemek için mikroplaklara Hep-2 hücreleri inoküle edilerek kuyucuklara farklı konsantrasyonlarda DMSO eklendi. Hücreler $37^{\circ} \mathrm{C}^{\prime}$ de $48-72$ saat inkübe edildi. İnkübasyon süresi sonunda "thiazolyl blue tetrazolium bromide (MTT)" deneyi ile kuyucuklardaki hücrelerin canlılığı belirlendi. Kontrol kuyucuğu ile aynı oranda hücre canlıığına sahip olan en yüksek DMSO konsantrasyonu çözücü konsantrasyonu olarak kullanıldı. Zeytin yaprağı ekstresi ve propolisin Hep-2 hücrelerine toksik olmayan konsantrasyonları belirlenerek antiviral aktivite çalışmaları belirlenen konsantrasyonlarda yapıldı. Steril membran filtreden süzülerek steril hale getirilen stok ekstre çözeltisindan propolis ve zeytin yaprağı ekstresinin farklı konsantrasyonları hazırlanarak Hep-2 hücreleri üzerine ayrı ayrı eklendi. Plaklar $37^{\circ} \mathrm{C}^{\prime}$ de $\% 5 \mathrm{CO}_{2}^{\prime}$ li inkübatörde 72 saat inkübe edildi. Inkübasyon süresi sonunda, hücreler üzerindeki kültür sıvısı alınarak hücreler fosfat tampon çözeltisi (PBS) ile yıkandı. Üzerlerine $1 \mathrm{mg} / \mathrm{ml}$ oranında MTT (Sigma, ABD) çözeltisi eklenen plaklar \%5 $\mathrm{CO}_{2}$ içeren $37^{\circ} \mathrm{C}^{\prime}$ lik etüvde üç saat inkübe edildi. İnkübasyon süresi sonunda MTT ile hücre canlılık oranları belirlendi. Kontrol kuyucuğu ile aynı oranda hücre canlılığına sahip olan propolis ve zeytin yaprağı ekstresi konsantrasyonları ile antiviral aktivite çalışmaları gerçekleştirildi. 


\section{Herpes Virüs Asiklovir Duyarlılığının Belirlenmesi}

Asiklovir (Sigma, PHR1254) üreticinin önerisi doğrultusunda 1 mg/ml konsantrasyonda distile su ile çözüldü ve uygun şekilde sulandırılarak, virüs üretim besiyeri içerisinde oranı $2048 \mu \mathrm{M}$ olacak şekilde hazırlandı. Bu çözeltiden yine virüs üretim besiyeri kullanılarak çift kat dilüsyonlar hazırlandı (2048-1 arası). Kültür plağında konfluent şekilde üretilen Hep-2 hücreleri üzerine asiklovir çözeltisi ve HSV-1 içeren sıvılar eklendi. Plak $\% 5 \mathrm{CO}_{2}$ içeren $37^{\circ} \mathrm{C}^{\prime}$ lik etüvde 72 saat inkübe edildi. İnkübasyon süresi sonunda her bir sütundaki sitopatik etki kontrol edildi.

\section{Zeytin Yaprağı Ekstresi ve Propolis Antiviral Aktiviteleri}

Önceden toksik olmayan dozları belirlenen zeytin yaprağı ekstresi ve propolisin, aşağıdaki oranlarda ve sürelerde HSV-1 üzerine etkisi araştırıldı.

$$
\text { Propolis: } \quad \begin{array}{ll} 
& 10 \mu \mathrm{g} / \mathrm{ml} \rightarrow 1 \text { saat ve } 3 \text { saat } \\
& 1 \mu \mathrm{g} / \mathrm{ml} \rightarrow 1 \text { saat ve } 3 \text { saat } \\
& 0.1 \mu \mathrm{g} / \mathrm{ml} \rightarrow 1 \text { saat ve } 3 \text { saat }
\end{array}
$$

Zeytin Yaprağı Ekstresi: $\quad 1.2 \mathrm{mg} / \mathrm{ml} \rightarrow 1$ saat ve 3 saat

$$
\begin{aligned}
& 200 \mu \mathrm{g} / \mathrm{ml} \rightarrow 1 \text { saat ve } 3 \text { saat } \\
& 120 \mu \mathrm{g} / \mathrm{ml} \rightarrow 1 \text { saat ve } 3 \text { saat }
\end{aligned}
$$

\begin{tabular}{|c|c|c|}
\hline $1.2 \mathrm{mg} / \mathrm{ml}$ & $200 \mu \mathrm{g} / \mathrm{ml}$ & $120 \mu \mathrm{g} / \mathrm{ml}$ \\
\hline $\begin{array}{l}\text { Zeytin } \\
\text { yaprağı } \\
\text { ekstresi }\end{array}$ & $\begin{array}{l}\text { Zeytin } \\
\text { yaprağı } \\
\text { ekstresi }\end{array}$ & $\begin{array}{l}\text { Zeytin } \\
\text { yaprağı } \\
\text { ekstresi }\end{array}$ \\
\hline HSV-1 & HSV-1 & HSV-1 \\
\hline
\end{tabular}

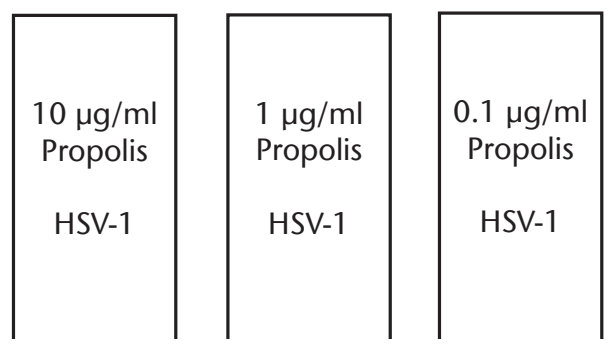
1. tüp
2. tüp
3. tüp
4. tüp
5. tüp
6. tüp 
Bu tüpler üç saat boyunca oda sıcaklığında bekletildi. Tüplerden birinci ve üçüncü saatlerde $50 \mu \mathrm{l}$ sıvı alınarak konvansiyonel yöntemde kullanılacak kuyucuklardaki hücreler üzerine ve RTCA yönteminde kullanılacak e-plaklar içerisindeki hücreler üzerine eklendi.

\section{Konvansiyonel Yöntem}

Içerisinde yukarıda belirtilen oranlarda etken madde ve $\log _{\mathrm{TCID}_{50}}: 11.5$ oranında HSV-1 bulunan tüpler, zeytin yaprağı ekstresi ve propolisin virüse etkisi açısından oda sıcaklığında inkübasyona bırakıldı. Bir saat ve üç saat sonunda tüplerden bir miktar sıvı alınarak enfektif virüs sayısını hesaplamak amacıyla, konfluent Hep-2 hücreleri içeren 96 kuyulu plaklara ekim yapıldı. Plaklar $\% 5 \mathrm{CO}_{2}$ içeren $37^{\circ} \mathrm{C}^{\prime}$ lik etüvde 72 saat inkübe edildi. İnkübasyon süresi sonunda tüm kuyucuklar incelenerek sitopatik etki varlığı araştıııldı ve hücre sayım işlemi gerçekleştirildi. TCID $_{50}$ değeri Spearman-Karber yöntemine göre hesaplandı.

\section{Gerçek Zamanlı Hücre Analiz Yöntemi}

Bu deney için, Hep-2 hücreleri, xCELLigence RTCA (ACEA Biosciences, San Diego, CA) cihazına ait 16 kuyucuklu e-plaklara ekildi. Plaklar RTCA cihazına yerleştirilerek $\% 5 \mathrm{CO}_{2}{ }^{\prime l i}$ ortamda $37^{\circ} \mathrm{C}^{\prime}$ de inkübasyona bırakıldı. Hücreler elektrotlara yerleşmeye başladığından itibaren ise sistemden geçen akım hücrelerin elektrik empedansı olarak izlendi. Yirmi dört saat sonra, üreyen hücreler üzerine, aşağıdaki şekilde hazırlanan karışımlar eklendi:

Cihazdaki programa ilgili komutlar girilerek, cihazın her 30 dakikada bir ölçüm yapması sağlandı. Plaklar RTCA cihazına yerleştirilerek $\% 5 \mathrm{CO}_{2}$ li ortamda $37^{\circ} \mathrm{C}^{\prime}$ de inkübasyona bırakıldı. Hücrelere ait veriler gerçek zamanlı olarak kaydedildi.

\section{Propolis-Zeytin Yaprağı Ekstresi, Propolis-Asiklovir ve Zeytin Yaprağı Ekstresi-Asiklovir Kombinasyonlarının HSV-1 Üzerine Etkilerinin Araştırılması}

Propolis-zeytin yaprağı ekstresi, propolis-asiklovir ve zeytin yaprağı ekstresi-asiklovir karışımlarının HSV-1 üzerine birlikte oluşturdukları etkilerinin araştırılması da RTCA cihazı ile gerçekleştirildi. Her üç maddenin de HSV-1 üzerine etkili olmadığı en yüksek konsantrasyonları (etkili oldukları konsantrasyondan en az dört kat düşük) seçildi (propolis $0.1 \mu \mathrm{g} /$ ml, zeytin yaprağı ekstresi $120 \mu \mathrm{g} / \mathrm{ml}$ ve asiklovir $256 \mu \mathrm{M}$ ). Buna göre aşağıdaki karışımlar hazırlandı:

\begin{tabular}{|c|c|c|}
\hline $\begin{array}{c}0.1 \mu \mathrm{g} / \mathrm{ml} \\
\text { Propolis } \\
+ \\
256 \mu \mathrm{M} \\
\text { Asiklovir } \\
+ \\
\text { HSV-1 }\end{array}$ & $\begin{array}{c}120 \mu \mathrm{g} / \mathrm{ml} \\
\text { Zeytin } \\
\text { yaprağı } \\
\text { ekstresi } \\
+ \\
256 \mu \mathrm{M} \\
\text { Asiklovir } \\
+ \\
\text { HSV-1 }\end{array}$ & $\begin{array}{c}0.1 \mu \mathrm{g} / \mathrm{ml} \\
\text { Propolis } \\
+ \\
120 \mu \mathrm{g} / \mathrm{ml} \\
\text { Zeytin } \\
\text { yaprağı } \\
\text { ekstresi } \\
+ \\
\text { HSV-1 }\end{array}$ \\
\hline
\end{tabular}


Hep-2 hücreleri, xCELLigence RTCA cihazına ait 16 kuyucuklu e-plaklara ekilerek $37^{\circ} \mathrm{C}$ ve \%5 $\mathrm{CO}_{2}^{\prime}$ li ortamda inkübasyona bırakıldı. Yirmi dört saat sonra, üreyen hücreler üzerine, yukarıdaki şekilde hazırlanan karışımlar eklendi. Cihazdaki programa ilgili komutlar girilerek, cihazın her 30 dakikada bir ölçüm yapması sağlandı. Plaklar RTCA cihazına yerleştirilerek $37^{\circ} \mathrm{C}$ ve $\% 5 \mathrm{CO}_{2}^{\prime}$ li ortamda inkübasyona bırakıldı. Hücrelere ait veriler gerçek zamanlı olarak kaydedildi.

\section{BULGULAR}

Çalışmanın ilk bölümünde, Spearman-Karber yöntemine göre HSV-1'in TCID ${ }_{50}$ değeri $11.5 \log _{10}$ olarak hesaplanmıştır. Konvansiyonel hücre kültürü yöntemi ile yapılan toksisite çalışmasında, Hep-2 hücrelerine toksik olmayan maksimum doz, DMSO için \%3, propolis için $10 \mu \mathrm{g} / \mathrm{ml}$ ve zeytin yaprağı ekstresi için $1.2 \mathrm{mg} / \mathrm{ml}$ olarak belirlenmiştir (Resim 1, 2).

Konvansiyonel yöntemle yapılan çalışmada, asiklovirin, $1024 \mu \mathrm{M}$ ve altındaki konsantrasyonlarda kullanıldığında, HSV-1 suşuna antiviral etkisinin olmadığı gözlenmiştir (Tablo I).

Propolis ve zeytin yaprağı ekstresinin farklı konsantrasyonlardaki ve iki farklı süredeki antiviral etkinlikleri hem konvansiyonel yöntemle hem de RTCA sistemiyle araştırılmıştır. Propolis ve zeytin yaprağı ekstrelerinin üç farklı konsantrasyonunun kullanıldığı ve bir saat ve üç saat süresince virüsle inkübe edildiği araştırmada, virüs miktarındaki en fazla azalmanın; propolis için $10 \mu \mathrm{g} / \mathrm{ml}$ dozunda, zeytin yaprağı ekstresi için ise $1.2 \mathrm{mg} / \mathrm{ml}$ konsantrasyonunda ilk bir saat içerisinde olduğu tespit edilmiştir (Tablo II, Şekil 1, 2).

Virüs inoküle edilen ve etken madde konulmayan kontrol hücrelerinin tamamında agregasyon, yuvarlaklaşma, nükleer genişleme gibi sitopatik etkiler gözlenmiştir

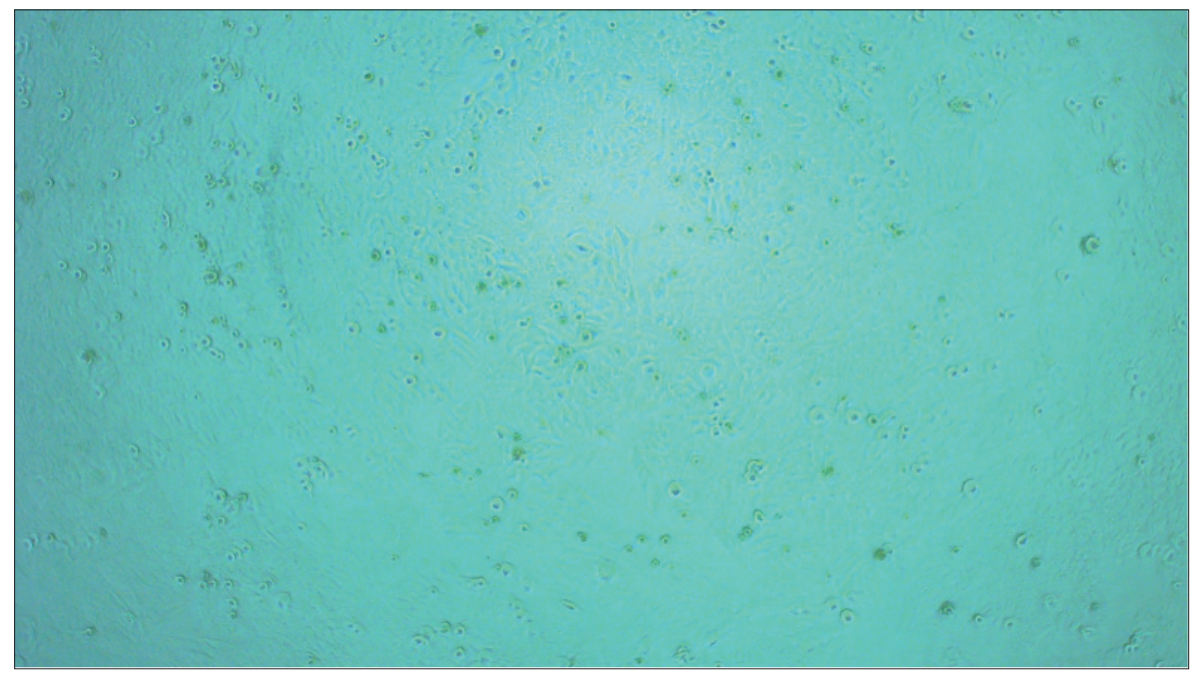

Resim 1. Toksik olmayan maksimum zeytin yaprağı ekstresi dozuna maruz bırakılan Hep-2 hücreleri görüntüsü (10x büyütme). 


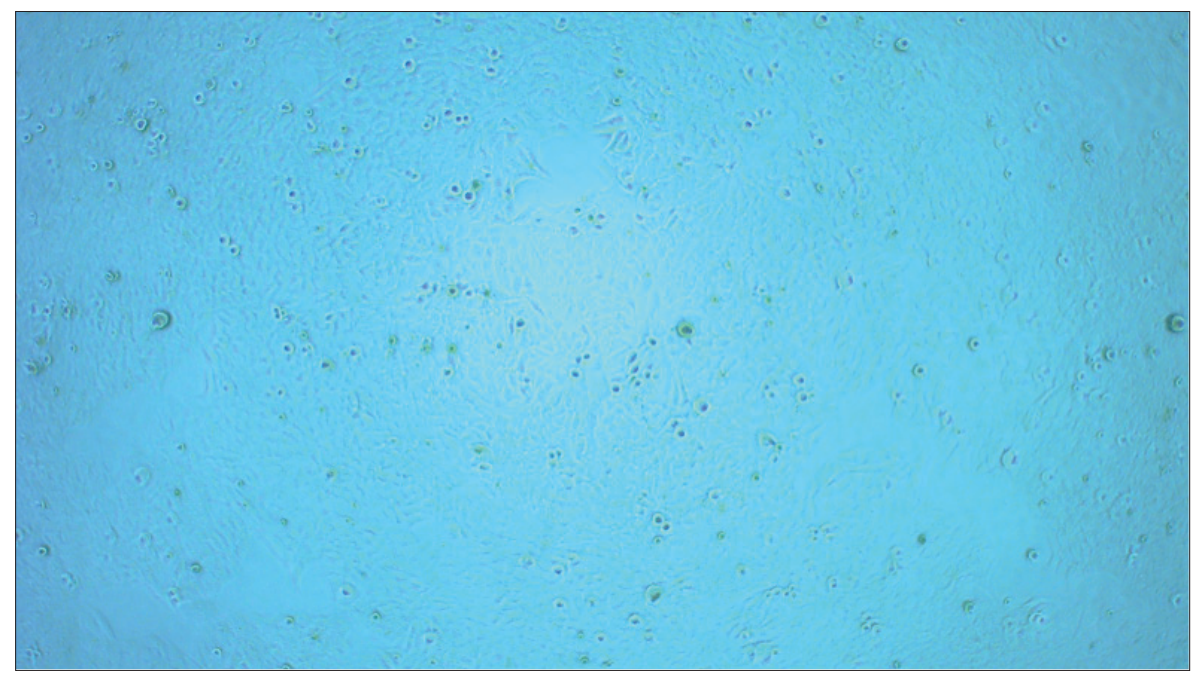

Resim 2. Toksik olmayan maksimum propolis dozuna maruz bırakılan Hep-2 hücreleri görüntüsü (10x büyütme).

\begin{tabular}{|c|c|c|c|c|c|c|c|c|c|c|c|c|}
\hline $\begin{array}{l}\text { Asiklovir } \\
\text { konsantrasyonu ( } \mu \mathrm{M})\end{array}$ & 2048 & 1024 & 512 & 256 & 128 & 64 & 32 & 16 & 8 & 4 & 2 & 1 \\
\hline $\begin{array}{l}\text { Kuyulardaki } \\
\text { pozitiflik oranı }\end{array}$ & $2 / 8$ & $7 / 8$ & $8 / 8$ & $8 / 8$ & $8 / 8$ & $8 / 8$ & $8 / 8$ & $8 / 8$ & $8 / 8$ & $8 / 8$ & $8 / 8$ & $8 / 8$ \\
\hline
\end{tabular}

\begin{tabular}{|c|c|c|c|c|c|c|}
\hline \multirow{2}{*}{\multicolumn{2}{|c|}{ Etken madde }} & \multicolumn{3}{|c|}{$\begin{array}{l}\text { Virüs sayısı } \\
\left(\log \mathrm{TCID}_{50}\right)\end{array}$} & \multicolumn{2}{|c|}{$\begin{array}{l}\text { Virüs sayısındaki azalma } \\
\left(\log \operatorname{TCID}_{50}\right)\end{array}$} \\
\hline & & \multirow{2}{*}{$\begin{array}{c}\text { Başlangıç } \\
11.5\end{array}$} & \multirow{2}{*}{$\begin{array}{c}1 \text { saat } \\
6.25\end{array}$} & \multirow{2}{*}{$\frac{3 \text { saat }}{4.15}$} & \multirow{2}{*}{$\begin{array}{c}1 \text { saat } \\
5.25\end{array}$} & \multirow{2}{*}{$\begin{array}{c}3 \text { saat } \\
7.35\end{array}$} \\
\hline Propolis & $10 \mu \mathrm{g} / \mathrm{ml}$ & & & & & \\
\hline & $1 \mu \mathrm{g} / \mathrm{ml}$ & 11.5 & 8.25 & 7.125 & 3.25 & 4.375 \\
\hline & $0.1 \mu \mathrm{g} / \mathrm{ml}$ & 11.5 & 11.25 & 11.125 & 0.25 & 0.375 \\
\hline \multirow{3}{*}{$\begin{array}{l}\text { Zeytin } \\
\text { yaprağı } \\
\text { ekstresi }\end{array}$} & $1.2 \mathrm{mg} / \mathrm{ml}$ & 11.5 & 7 & 5.5 & 4.5 & 6 \\
\hline & $200 \mu \mathrm{g} / \mathrm{ml}$ & 11.5 & 9 & 7.375 & 2.5 & 4.125 \\
\hline & $120 \mu \mathrm{g} / \mathrm{ml}$ & 11.5 & 11.25 & 11 & 0.25 & 0.5 \\
\hline
\end{tabular}

(Resim 3). Etken maddelerin antiviral etkinliklerinin görüldüğü dozların uygulandığı hücrelerde sitopatik etkiler görülmemiştir. 


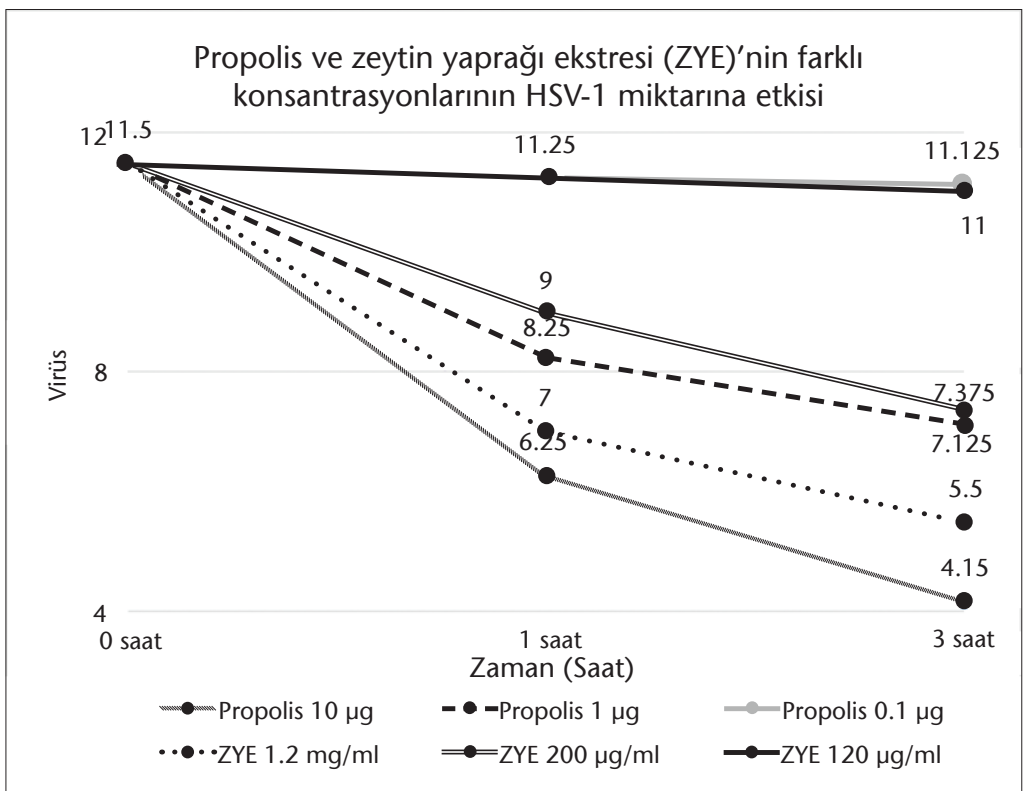

Şekil 1. Propolis ve zeytin yaprağı ekstresinin farklı konsantrasyonlarının zamanla HSV-1 miktarına etkisi.

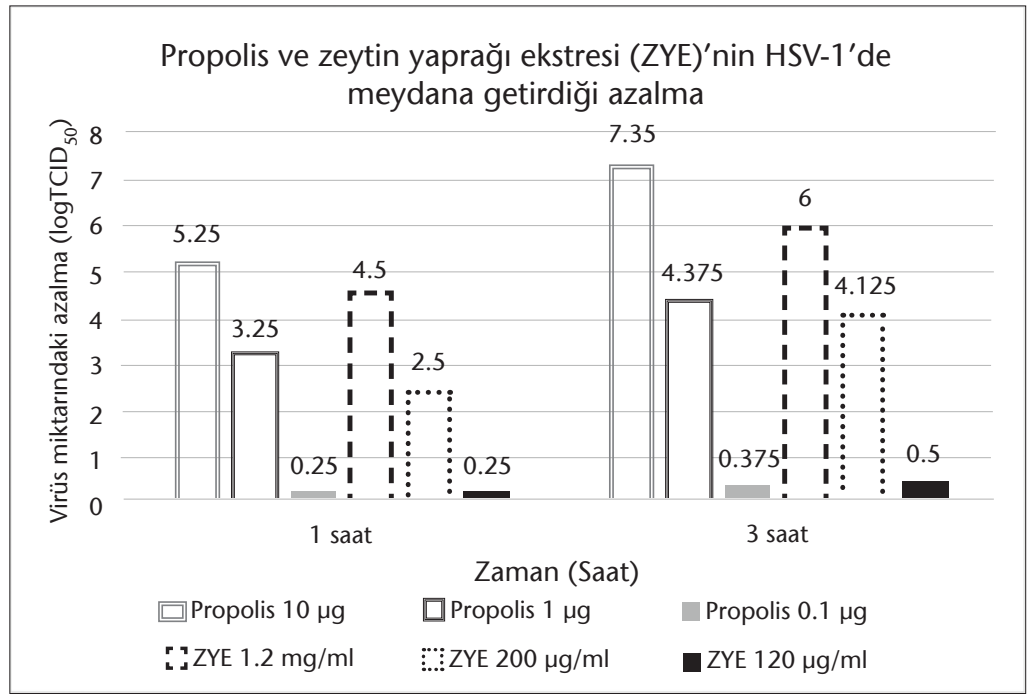

Şekil 2. Propolis ve zeytin yaprağı ekstresinin HSV-1'de meydana getirdiği azalma.

Gerçek zamanlı hücre görüntüleme sistemi ile yapılan çalışmada, propolisin $10 \mu \mathrm{g} / \mathrm{ml}$ dozunda bir saat ve üç saatlik inkübasyonlarda antiviral etkinliğin olduğu tespit edilmiştir (Şekil 3, Tablo III). Bununla birlikte, $1 \mu \mathrm{g} / \mathrm{ml}$ dozunda ve virüsle bir saat inkübe edilen propolisin antiviral etkisinin azaldığı, sitopatik etki oluşumunun önlenmesinde yetersiz 


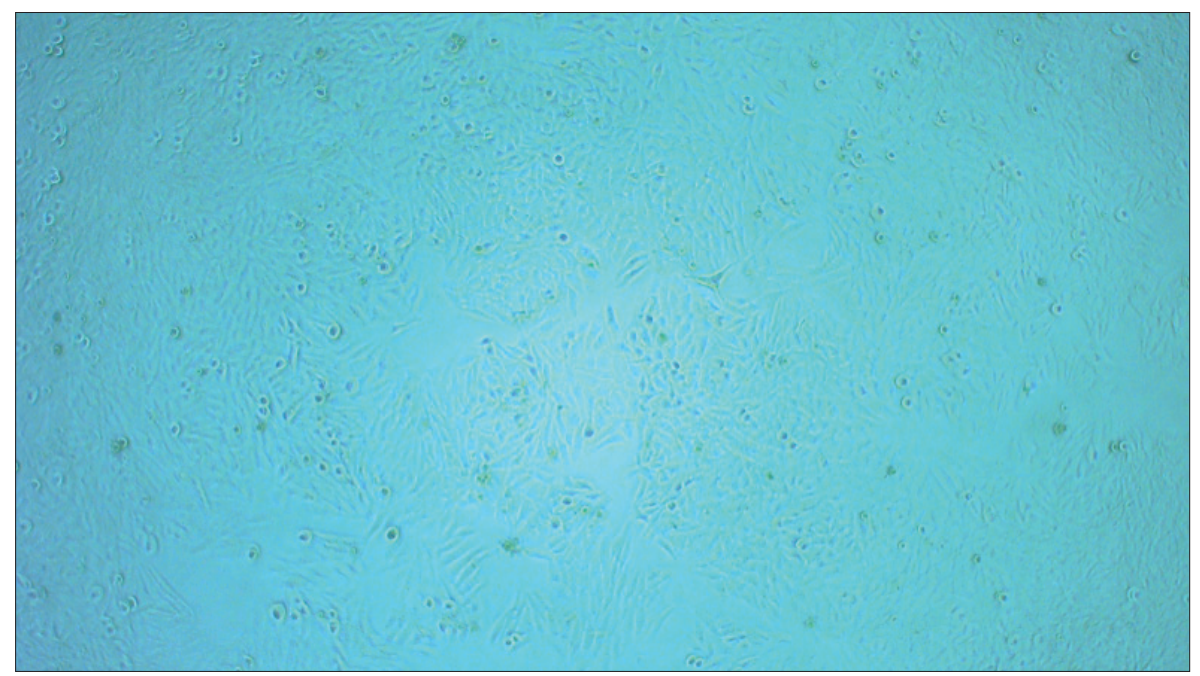

Resim 3. Kontrol hücrelerinde meydana gelen sitopatik etkiler (10x büyütme).

kaldığı (Şekil 3, Tablo III) ve 48. saatte sitopatik etki oluşumunun izlenmeye başladığı belirlenmiştir. Propolisin $0.1 \mu \mathrm{g} / \mathrm{ml}$ dozunda ise virüsle hem bir saat hem de üç saat inkübasyon sonrası yapılan her iki çalışmada da, 42. saatte sitopatik etki belirtileri başlamıştır (Şekil 3, Tablo III). Zeytin yaprağı ekstresi ile yapılan değerlendirmede; 1.2 mg/ml

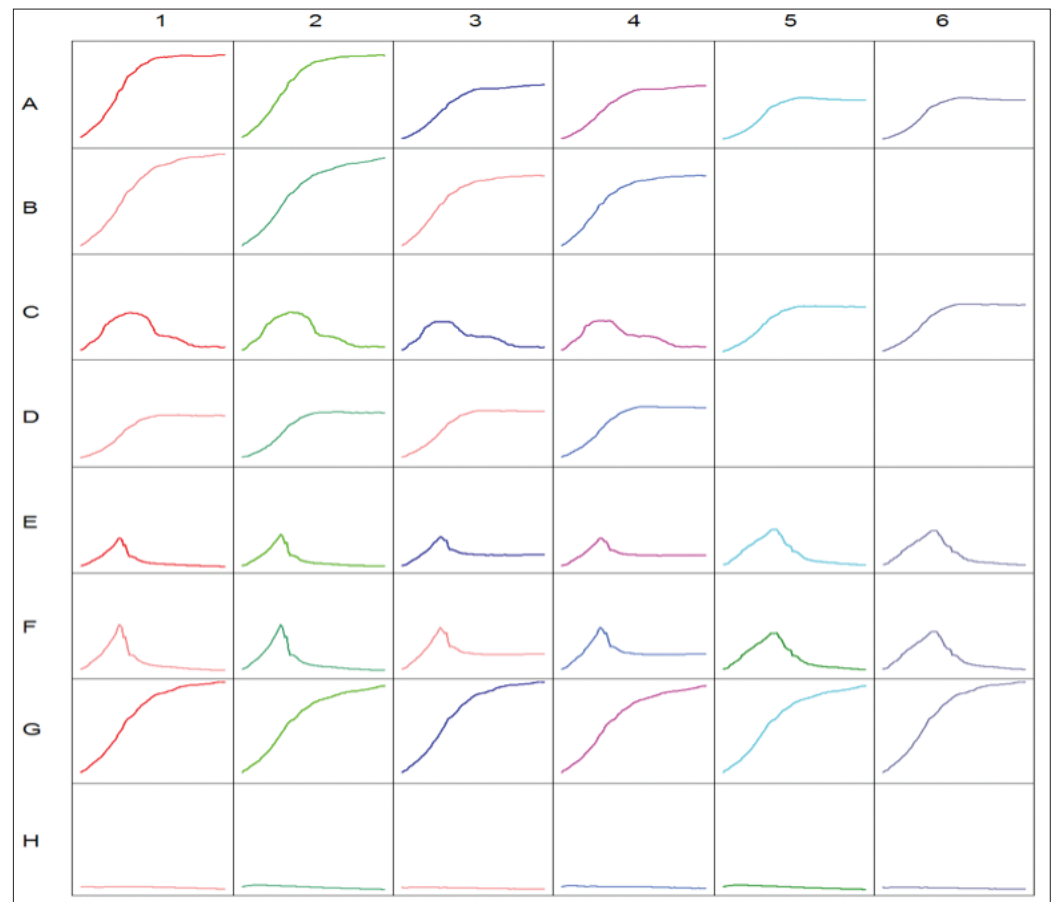

Şekil 3. RTCA analizine ait sonuç grafikleri. 


\begin{tabular}{|c|c|c|c|c|c|c|}
\hline & 1 & 2 & 3 & 4 & 5 & 6 \\
\hline \multirow[t]{4}{*}{$A$} & Propolis & Propolis & ZYE & ZYE & Propolis & Propolis \\
\hline & $10 \mu \mathrm{g} / \mathrm{ml}$ & $10 \mu \mathrm{g} / \mathrm{ml}$ & $1.2 \mathrm{mg} / \mathrm{ml}$ & $1.2 \mathrm{mg} / \mathrm{ml}$ & $0.1 \mu \mathrm{g} / \mathrm{ml}-1$ saat & $0.1 \mu \mathrm{g} / \mathrm{ml}-3$ saat \\
\hline & 1 saat & 1 saat & 1 saat & 1 saat & Asiklovir & Asiklovir \\
\hline & & & & & $256 \mathrm{nM}$ & $256 \mathrm{nM}$ \\
\hline \multirow[t]{3}{*}{ B } & Propolis & Propolis & ZYE & ZYE & Boş kuyucuk & Boş kuyucuk \\
\hline & $10 \mu \mathrm{g} / \mathrm{ml}$ & $10 \mu \mathrm{g} / \mathrm{ml}$ & $1.2 \mathrm{mg} / \mathrm{ml}$ & $1.2 \mathrm{mg} / \mathrm{ml}$ & & \\
\hline & 3 saat & 3 saat & 3 saat & 3 saat & & \\
\hline \multirow[t]{4}{*}{$C$} & Propolis & Propolis & ZYE & ZYE & ZYE & ZYE \\
\hline & $1 \mu \mathrm{g} / \mathrm{ml}$ & $1 \mu \mathrm{g} / \mathrm{ml}$ & $200 \mu \mathrm{g} / \mathrm{ml}$ & $200 \mu \mathrm{g} / \mathrm{ml}$ & $120 \mu \mathrm{g} / \mathrm{ml}-1$ saat & $120 \mu \mathrm{g} / \mathrm{ml}-3$ saat \\
\hline & 1 saat & 1 saat & 1 saat & 1 saat & Asiklovir & Asiklovir \\
\hline & & & & & $256 \mathrm{nM}$ & $256 \mathrm{nM}$ \\
\hline \multirow[t]{3}{*}{ D } & Propolis & Propolis & ZYE & ZYE & Boş kuyucuk & Boş kuyucuk \\
\hline & $1 \mu \mathrm{g} / \mathrm{ml}$ & $1 \mu \mathrm{g} / \mathrm{ml}$ & $200 \mu \mathrm{g} / \mathrm{ml}$ & $200 \mu \mathrm{g} / \mathrm{ml}$ & & \\
\hline & 3 saat & 3 saat & 3 saat & 3 saat & & \\
\hline \multirow[t]{5}{*}{$E$} & Propolis & Propolis & ZYE & ZYE & Propolis & Propolis \\
\hline & $0.1 \mu \mathrm{g} / \mathrm{ml}$ & $0.1 \mu \mathrm{g} / \mathrm{ml}$ & $120 \mu \mathrm{g} / \mathrm{ml}$ & $120 \mu \mathrm{g} / \mathrm{ml}$ & $0.1 \mu \mathrm{g} / \mathrm{ml}$ & $0.1 \mu \mathrm{g} / \mathrm{ml}$ \\
\hline & 1 saat & 1 saat & 1 saat & 1 saat & ZYE & ZYE \\
\hline & & & & & $120 \mu \mathrm{g} / \mathrm{ml}$ & $120 \mu \mathrm{g} / \mathrm{ml}$ \\
\hline & & & & & 1 saat & 1 saat \\
\hline \multirow[t]{5}{*}{$\mathrm{F}$} & Propolis & Propolis & ZYE & ZYE & ZYE & ZYE \\
\hline & $0.1 \mu \mathrm{g} / \mathrm{ml}$ & $0.1 \mu \mathrm{g} / \mathrm{ml}$ & $120 \mu \mathrm{g} / \mathrm{ml}$ & $120 \mu \mathrm{g} / \mathrm{ml}$ & $120 \mu \mathrm{g} / \mathrm{ml}$ & $120 \mu \mathrm{g} / \mathrm{ml}$ \\
\hline & 3 saat & 3 saat & 3 saat & 3 saat & Propolis & Propolis \\
\hline & & & & & $0.1 \mu \mathrm{g} / \mathrm{ml}$ & $0.1 \mu \mathrm{g} / \mathrm{ml}$ \\
\hline & & & & & 3 saat & 3 saat \\
\hline G & $\begin{array}{l}\text { Hücre } \\
\text { kontrol }\end{array}$ & $\begin{array}{l}\text { Hücre } \\
\text { kontrol }\end{array}$ & $\begin{array}{l}\text { Hücre } \\
\text { kontrol }\end{array}$ & $\begin{array}{l}\text { Hücre } \\
\text { kontrol }\end{array}$ & $\begin{array}{l}\text { Hücre } \\
\text { kontrol }\end{array}$ & $\begin{array}{l}\text { Hücre } \\
\text { kontrol }\end{array}$ \\
\hline $\mathrm{H}$ & Besiyeri & Besiyeri & Besiyeri & Besiyeri & Besiyeri kontrol & Besiyeri \\
\hline
\end{tabular}

konsantrasyonda, bir saat ve üç saatlik inkübasyonlarda antiviral etkinliğinin olduğu tespit edilmiştir. Bununla birlikte, $200 \mu \mathrm{g} / \mathrm{ml}$ konsantrasyonunda bir saatlik inkübasyon sonrası yapılan çalışmada, antiviral etkinlik azalmış ve 46. saatte sitopatik etki gözlenmeye başlamıştır (Şekil 3, Tablo III). Çalışılan en düşük zeytin yaprağı ekstresi konsantrasyonunda $(120 \mu \mathrm{g} / \mathrm{ml})$ ise her iki saatte de antiviral etkinin yetersiz kaldığı ve 41. saatte sitopatik etki oluşmaya başladığı tespit edilmiştir (Şekil 3, Tablo III).

Propolis-zeytin yaprağı ekstresi, propolis-asiklovir ve zeytin yaprağı ekstresi-asiklovir karışımlarının HSV-1 üzerine birlikte etkilerinin araştııılması amacıyla etken madde kombinasyonlarının etkilerinin değerlendirilmesinin yapıldığı çalışmada, tek başlarına etkili 
oldukları en düşük konsantrasyondan en az dört kat daha düşük konsantrasyonları kullanılmıştır. Propolis ve zeytin yaprağı ekstresinin her ikisi de asiklovir ile birlikte kullanıldığında sitopatik etkinin gelişmediği, propolis ve zeytin yaprağı ekstresi birlikteliğinde ise sitopatik etkinin geciktiği (54. saat) belirlenmiştir (Şekil 3, Tablo III).

\section{TARTIŞMA}

Dünya genelinde oldukça yaygın bir klinik problem olan HSV enfeksiyonları özellikle immünitenin baskılandığı koşullarda reaktivasyonlara yol açmakta ve ciddi komplikasyonlara neden olabilmektedir ${ }^{4,5}$. Bu enfeksiyonlarda sık ilaç kullanımı sonucunda artan ilaç direnci, herpes virüs tedavisinde, daha güçlü ve kolayca erişilebilen yeni aktif moleküllerin araştırılmasını teşvik etmektedir ${ }^{6}$. Son zamanlarda, antiviral ilaç araştırmaları, düşük toksisitesi nedeniyle doğal ürünler üzerinde yoğunlaşmıştır ${ }^{13,14}$. Bu çalışmada, iki doğal ürünün (propolis ve zeytin yaprağı ekstresi) HSV üzerine antiviral etkinliği olup olmadığı asiklovir ile karşılaştırılarak araştırılmıştır.

Propolis, bal arılarının çeşitli bitki kaynaklarından toplayıp balmumu ile karıştırdığı, antimikrobiyal etkili olduğu bilinen, reçineli bir maddedir. Geniş bir biyolojik aktiviteye, antimikrobiyal, antienflamatuvar ve antioksidan etkiler gibi birçok farmakolojik özelliklere sahip olan propolis, eski çağlardan beri geleneksel bir doğal ilaç olarak kullanılmakta$d^{\prime \prime}{ }^{15}$. Önceki araştırmalarda, toksik olmayan bu doğal ürünün, insanlarda ve hayvanlarda, alerji ve kontakt dermatit dışında, çok az yan etki oluşturduğu bildirilmiştir ${ }^{16-18}$. Propolisin kimyasal bileşimi, coğrafi köken ve bölgesel floraya bağlı olarak nitelik ve nicelik bakımından değişkenlik göstermektedir. Buna rağmen içeriğinde, fiziko-kimyasal özelliklerini belirleyen, özellikle de farmakodinamik özelliklere sahip flavonoidler, fenoller ve terpenler her zaman bulunur. Benzer biyolojik aktivitelere sahip preparatlar elde etmek ve kantitatif bileşimdeki bazı farklılıkların ortadan kaldırılması için aynı coğrafi alandaki propolis örneklerinin kullanılması gerekmektedir ${ }^{19}$.

Çalışmamızda kullanılan bir diğer etken madde zeytin ağacı yapraklarından elde edilmiştir. Zeytin ağacı yaprakları Yunanistan, İspanya, İtalya, Fransa, Türkiye, İsrail, Fas ve Tunus gibi Avrupa ve Akdeniz ülkelerinde, ekstraktlar, bitkisel çaylar ve toz şeklinde geleneksel tedavilerde yaygın olarak kullanılmaktadır. Bu nedenle, çeşitli alanlardaki bilim insanlarının, zeytin yapraklarının sağlık üzerindeki olası yararlarına olan ilgisi $\operatorname{artmıştır~}^{11,20}$. Zeytin yaprağı fenolik asitlere, fenolik alkollere, flavonoidlere ve sekoiridoidlere ait çok çeşitli fenolik bileşikler içerir. Zeytin ağacında (zeytin yaprağı, tohum, hamur ve olgunlaşmamış zeytin) bulunan ve önemli biyolojik özelliklere sahip fenolik bileşiklerden olan oleuropeinin antioksidan, antimikrobiyal, antienflamatuvar, antiaterojenik, kardiyoprotektif, nöroprotektif, antikarsinojenik gibi birçok yararlı özelliği olduğu gösterilmiştir ${ }^{9,21,22}$. Zeytin yaprağı ekstresinin, düşük konsantrasyonlarda antibakteriyel ve antifungal etkilerin yanı sıra grip ve soğuk algınlığında antiviral aktivite gösterdiği bildirilmiştir ${ }^{11}$. Zeytin yaprağı ekstresinin antiviral aktivitesinin, virüs partiküllerinin hücreye bağlanmasını ve adsorpsiyonu önleyerek hücrelere girişlerini bloke ettiği tespit edilmiştir ${ }^{23}$. 
Çalışmamızda, Sakarya bölgesinden elde edilen propolis ve zeytin yaprağı ekstresinin üç farklı konsantrasyonda iki farklı sürede yapılan değerlendirmesinde, ekstraktlar virüslerle önceden muamele edilerek hücre kültürü ortamına eklenmiştir. Hem konvansiyonel hücre kültürü hem de RTCA sisteminde, her iki ekstraktın da HSV-1 üzerine antiviral etkileri olduğu gösterilmiştir.

Propolis için, $0.1 \mu \mathrm{g} / \mathrm{ml}$ dozunda virüsle inkübasyon sonrası sitopatik etki oluşumunun önlenemediği, $1 \mu \mathrm{g} / \mathrm{ml}$ dozunda bir saat inkübasyon ile virüs sayısında belirgin bir azalma görülmeye başlarken sitopatik etki oluşumunun önlenmesinde yeterince etkili olmadığı, $10 \mu \mathrm{g} / \mathrm{ml}$ konsantrasyonunda bir saat ve üç saatlik inkübasyonlarda antiviral etkinin oluştuğu gözlenmiştir. Ülkemizde, Hatay Bölgesinde, Yıldırım ve arkadaşlarının yaptıkları çalışmada ${ }^{6}$ propolisin $100 \mu \mathrm{g} / \mathrm{ml}$ konsantrasyonunda sitopatik etki gelişimini tam olarak önleyebildiği bildirilmiştir. Bankova ve arkadaşları da yaptıkları çalışmada ${ }^{15}$, propolis ekstraktının HSV-1'e karşı belirgin bir virüsidal etkiye sahip olduğunu ve virüsün adsorpsiyonunda da etkisinin olduğunu göstermişlerdir. HSV-1'e karşı propolis ekstraktının, 1 mg/ml konsantrasyonda üç saat temas sonrasında bazı etkilerinin oluşmaya başladığı, $3.2 \mathrm{mg} / \mathrm{ml}$ ile en az 15 dakikalık temas sonrasında etkilerinin belirginleştiği, kesin virüsidal etkinin ise $10 \mathrm{mg} / \mathrm{ml}$ veya daha yüksek konsantrasyonlarda ve en az 15 dakikalık bir temas süresiyle oluştuğu gözlemlenmiştir. Çalışmamızda elde edilen sonuçlardaki konsantrasyon farklılığının, propolisin elde edildiği bölge, toplanma zamanı ve kullanılan hücre hattının farklı olmasından kaynaklanıyor olabileceği düşünülmüştür.

Bazı çalışmalarda, herpes virüsün propolis ile ön muamelesinin virüsidal etkili olduğu, propolis ekstraktının viral enfeksiyon öncesinde veya sırasında hücre kültürüne eklenmesinin virion zarf yapılarına etki ettiği veya konakçı hücrelere giriş yapmak için gerekli olan viral bileşikleri maskeleyerek virüsün hücre içine girişini önlediği bildirilmiştir. Ekstraktların veya bileşiklerin, virüslerin konakçı hücrelere penetrasyonundan sonra ortama eklenmesinin ise plak oluşumunu önemli ölçüde azaltmadığı tespit edilmiştir ${ }^{24-26}$.

Çalışmamızda, zeytin yaprağı ekstresi kullanımı ile virüs miktarındaki azalmanın en fazla $1.2 \mathrm{mg} / \mathrm{ml}$ konsantrasyonda ilk bir saat içerisinde olduğu tespit edilmiştir. Zeytin yaprağı ekstresi ile yapılan antimikrobiyal çalışmaların çoğu fungal ve bakteriyel etkenlerle yapılmış olup, virüslerle yapılan toplam üç çalışmaya ulaşılabilmiştir. Bu çalışmalardan ikisinde oleuropeinin HIV-1 (insan immün yetmezlik virüsü) ve VHSV (viral hemorajik septisemi virüsü) üzerine olan etkileri araştırılırken diğer bir çalışmada zeytin yaprağı ekstresinin HSV-1 üzerine etkisi araştırılmıştı ${ }^{14}$. Motamedi Far ve arkadaşları yaptıkları çalışmada ${ }^{27}$, zeytin yaprağı ekstresinin, HSV-1 ile Vero hücre enfeksiyonundan bir saat öncesinde uygulandığında, $1 \mathrm{mg} / \mathrm{ml}$ ve $1.25 \mathrm{mg} / \mathrm{ml}$ konsantrasyonunda kontrol numunelerine kıyasla viral plaklarda anlamlı $(\mathrm{p}<0.05)$ bir azalma sağladığını; daha düşük konsantrasyonlarda böyle bir etkisinin olmadığını göstermişlerdir. Hücrelerin HSV-1 ile enfekte edilmesinden bir saat sonra hücre kültürüne uygulandığında ise antiviral aktivite görülmediğini saptamışlardır. Virüslerin, hücre kültürüne eklenmeden önce $<1 \mathrm{mg} / \mathrm{ml}$ zeytin yaprağı ekstresi ile bir saat süresince oda sıcaklığında inkübasyonu, virüs sayısını önemli ölçüde değiş- 
tirmemiştir. Bununla birlikte, ekstrenin $\geq 1 \mathrm{mg} / \mathrm{ml}$ konsantrasyonlarında, virüs sayısını önemli ölçüde azalttığı $(p<0.05)$ bildirilmiştir.

Asiklovir, HSV'de DNA replikasyonunu önleyen bir guanozin nükleoz(t)it analoğudur ${ }^{28}$. Bununla birlikte, aktif olması için HSV timidin kinaz ile fosforile edilmesi gerekir ve sadece aktif HSV replikasyonu sırasında etki gösterir. Bazı HSV mutantları, timidin kinaz aktivitesinden yoksundur ve dolayısıyla asiklovire dirençlidir. Böyle bir direnç, HSV enfeksiyonlarının tedavisinde büyük bir problem oluşturmaktadır ${ }^{27}$. Ilaç direnci gelişiminin engellenmesi, ilaç toksik etkilerinin azaltılması ve antimikrobiyal spektrumun genişletilmesi gibi avantajlar için etken madde kombinasyonları ile sinerji etkisinden yararlanılabilir. Bu, farklı hedefleri farklı ya da aynı mekanizma ile aynı hedefi farklı mekanizma ile inhibe ederek oluşturulabilir ${ }^{29}$.

Sinerjist etki deneysel olarak, kombinasyonu oluşturan her bir antibiyotiğin minimum inhibitör konsantrasyonu (MiK) değerinde dört kat düşüş olmasıyla belirlenmektedir ${ }^{29}$. Araştırmamızın bir diğer basamağında, asiklovir ve ekstraktların tek başlarına etkili oldukları en düşük konsantrasyondan daha düşük konsantrasyonlar (asiklovir için dört kat, ekstraktlar için on kat daha az) kullanılarak hazırlanan ikişerli kombinasyonlarının antiviral etkinlikleri değerlendirilmiş, asiklovir ile olan kombinasyonlarda sitopatik etki görülmezken birlikte kullanıldıklarında sitopatik etki oluşumunun geciktiği gözlenmiştir.

Çalışmamızda kullanılan ekstraktların ve asiklovirin, tek başlarına etkili olmadıkları konsantrasyonları kullanılarak, birbirleriyle ve asiklovir ile hazırlanan ikili kombinasyonlarında, sitopatik etki oluşumunun geciktiği ya da önlendiği belirlenmiştir. HSV-1'e karşı asiklovir ve propolis veya zeytin yaprağı ekstresi ile hazırlanan kombinasyonlarda sinerji olabileceği tespit edilmiştir. Virüsün bölünmesini etkileyen bazı propomik bileşenlerin asiklovirin etkisini artırabileceği düşünülmüştür. Nitekim literatürde bazı çalışmalarda da HSV'ye karşı asiklovir ile propolis veya zeytin yaprağı ekstresi arasında güçlü bir sinerji olabileceği öne sürülmüştür ${ }^{6}$.

Propolis içeriğinin belirlenememiş olması ve daha düşük dozlarda kombinasyon çalışmalarının yapılamamış olması çalışmamızı kısıtlayan faktörler olarak belirlenmiştir.

Bu çalışmada, Sakarya Bölgesinden elde edilen, propolis ve zeytin yaprağı ekstraktlarının, HSV-1 replikasyonuna karşı etkili olduğu gösterilmiştir. Ayrıca, propolis ve zeytin yaprağı ekstrelerinin asiklovir ile olan kombinasyonlarında, tek başlarına etkili oldukları minimum konsantrasyonların daha altında da etki gösterebildiklerinin tespiti, bu ekstrelerin, HSV-1 enfeksiyonu için, asiklovire alternatif ya da dozunu azaltmaya yardımcı etken maddeler olabileceğini düşündürmektedir.

Bizim sonuçlarımız zeytin yaprağı ekstresi ve propolisin, virüsün hücreye penetre olmasından önceki aşamada etkili olduğu görüşü ile uyumludur. Timidin kinaz tarafından bir aktif forma dönüştürülmeleri gerekmediğinden, klinik çalışmalarda dirençli HSV-1'in tedavisi için yeni bir seçenek olarak düşünülebilirler.

Zeytin yaprağı ekstresi ve propolisin HSV-1 üzerine olan etkisi, herpetik oral lezyonların enfektivitesinin azaltılmasında, kişisel temasta oral sıvılardaki çapraz kontaminasyon 
riskinin ve virüsün asemptomatik yayılımının önlenmesinde kullanılabileceğini göstermektedir. Ayrıca, immün sistem defekti olan hastalarda asiklovire dirençli HSV lezyonlarının topikal tedavisinde yeni bir seçenek olarak umut vericidirler. Bununla birlikte, bu ekstraktların farmakokinetiği ve antimikrobiyal özelliklerini in vivo koşullarda ne kadar devam ettirebildikleri konusunda daha fazla çalışmaya ihtiyaç bulunmaktadır. Yapılacak daha ileri çalışmalarla, daha geniş bir mikroorganizma yelpazesine karşı değerlendirilerek yeni terapötik uygulama alanları bulunabilir.

\section{ÇIKAR ÇATIŞMASI}

Yazarlar bu makale ile ilgili herhangi bir çıkar çatışması bildirmemişlerdir.

\section{KAYNAKLAR}

1. Lavoie S, Côté I, Pichette A, Gauthier C, Ouellet M, Nagau-Lavoie F, et al. Chemical composition and antiherpes simplex virus type 1 (HSV-1) activity of extracts from Cornus canadensis. BMC Complement Altern Med 2017;17(1):123.

2. Yağmur $\mathrm{G}$, Ozbal Y, Gökahmetoğlu S. Investigation of herpes simplex virus (HSV) by three different methods in the clinical specimens of patients with suspected HSV infections. Mikrobiyol Bul 2010;44(1):47-56.

3. Pourchet A, Modrek AS, Placantonakis DG, Mohr I, Wilson AC. Modeling HSV-1 latency in human embryonic stem cell-derived neurons. Pathogens 2017;6(2):E24.

4. Anderson NW, Buchan BW, Ledeboer NA. Light microscopy, culture, molecular, and serologic methods for detection of herpes simplex virus. J Clin Microbiol 2014;52(1):2-8.

5. Çolak D, Mutlu D. Herpes grubu viruslar, pp: 509-52. In: Us AD, Ergünay K (eds), Moleküler, Klinik ve Tanısal Viroloji. 2012, Bilimsel Tıp Yayınevi, Ankara.

6. Yildirim A, Duran GG, Duran N, Jenedi K, Bolgul BS, Miraloglu M, et al. Antiviral activity of Hatay propolis against replication of herpes simplex virus type 1 and type 2. Med Sci Monit 2016;9(22):422-30.

7. Motamedifar M, Ghafari N, Shirazi PT. The effect of cumin seed extracts against herpes simplex virus type 1 in vero cell culture. Iran J Med Sci 2010;35(4):304-9.

8. Tian D, Zhang W, He J, Liu Y, Song Z, Zhou Z, et al. Novel, real-time cell analysis for measuring viral cytopathogenesis and the efficacy of neutralizing antibodies to the 2009 influenza A (H1N1) virus. PLoS One 2012;7(2):e31965.

9. Fang $Y, Y e P$, Wang $X, X u X$, Reisen W. Real-time monitoring of flavivirus induced cytopathogenesis using cell electric impedance technology. J Virol Methods 2011;173(2):251-8.

10. Teng Z, Kuang X, Wang J, Zhang X. Real-time cell analysis--a new method for dynamic, quantitative measurement of infectious viruses and antiserum neutralizing activity. J Virol Methods 2013;193(2):364-70.

11. Khattab RA, Shawky Hosny AE, Abdelkawy MA, Fahmy RH, EIMenoufy NA. Anti-HSV type-1 activity of olive leaves extract crude form acting as a microemulsion dosage form. Afr J Microbiol Res 2016;10(22):820-8.

12. Hierholzer JC, Killington RA. Virus isolation and quantitation, pp: 25-46 In: Brain WJM, Hillar OK (eds), Virology Methods Manual, 1996. Academic Press.

13. Newman DJ, Cragg GM. Natural products as sources of new drugs over the 30 years from 1981 to 2010. J Nat Prod 2012;75(3):311-35.

14. Atai Z, Khoshroo SMR, Rezvaninejad, Rezvaninejad R, Torabi N. Antimicrobial efficacy of olive leaf extract antimicrobial efficacy of olive leaf extract: A systematic review of in vitro study. Adv Biores 2016;7(6):205-12.

15. Bankova V, Galabov AS, Antonova D, Vilhelmova N, Di Perri B. Chemical composition of propolis extract $\mathrm{ACF}^{\circledR}$ and activity against herpes simplex virus. Phytomedicine 2014;21(11):1432-8.

16. Mani F, Damasceno HCR, Novelli ELB, Sforcin JM. Biochemical determinations of propolis-treated rats: effects of different concentrations, extracts and intake period. Biosaude 2008;10(1):3-16. 
17. Callejo A, Armentia A, Lombardero M, Asensio T. Propolis, a new bee-related allergen. Allergy 2001;56(6):579.

18. Rudeschko O, Machnik A, Dorfelt H, Kaatz HH, Schlott B, Kinne RW. A novel inhalation allergen present in the working environment of beekeepers. Allergy 2004;59(3):332-7.

19. Hazem A, Pitica-Aldea IM, Popescu C, Matei L, Dragu D, Economescu M, et al. The antiviral/virucidal effects of alcholic and aqueous extracts with propolis. Farmacia 2017;65(6):868-76.

20. EI SN, Karakaya S. Olive tree (Olea europaea) leaves: potential beneficial effects on human health. Nutr Rev 2009;67(11):632-8.

21. Bakir M, Geyikoglu F, Koc K, Cerig S. Therapeutic effects of oleuropein on cisplatin-induced pancreas injury in rats. J Cancer Res Ther 2018;14(3):671-8.

22. Yıldız G, Uylaşer V. Doğal bir antimikrobiyal: Oleuropein. Uludağ Üniversitesi Ziraat Fakültesi Dergisi $2011 ; 25(1): 131-42$

23. Micol V, Caturla N, Pérez-Fons L, Más V, Pérez L, Estepa A. The olive leaf extract exhibits antiviral activity against viral haemorrhagic septicaemia rhabdovirus (VHSV). Antiviral Res 2005;66(2-3):129-36.

24. Huleihel M, Isanu V. Anti-herpes simplex virus effect of an aqueous extract of propolis. Isr Med Assoc J 2002;4(11):923-7.

25. Amoros M, Lurton E, Boustie J, Girre L. Comparison of the anti-herpes simplex virus activities of propolis and 3-methyl-but-2-enyl caffeate. J Nat Prod 1994;5(5):644-7.

26. Schnitzler P, Neuner A, Nolkemper S, Zundel C, Nowack H, Sensch KH, et al. Antiviral activity and mode of action of propolis extracts and selected compounds. Phytother Res 2010;24(1):20-8.

27. Motamedifar M, Nekooeian AA, Moatari A. The effect of hydroalcoholic extract of olive leaves against herpes simplex virus type 1. Iran J Med Sci 2007;32(4):222-6.

28. Bacon TH, Levin MJ, Leary JJ, Sarisky RT, Sutton D. Herpes simplex virus resistance to acyclovir and penciclovir after two decades of antiviral therapy. Clin Microbiol Rev 2003;16(1):114-28.

29. Aktaş G. Antibiyotik kombinasyonları ve sinerjistik etkileşimleri. Türk Mikrobiyol Cem Derg 2014;44(2):4755. 